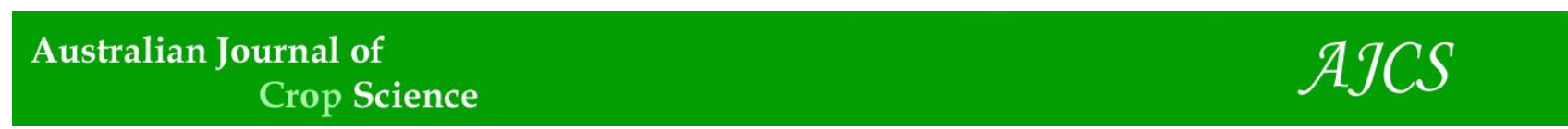

AJCS 10(12):1669-1674 (2016)

ISSN:1835-2707

doi: 10.21475/ajcs.2016.10.12.p7741

\title{
Effects of sources and split application of nitrogen fertilizer on wheat genotypes performance
}

\author{
Mauricio Ferrari ${ }^{1}$, Vinícius Jardel Szareski ${ }^{2}$, Maicon Nardino* ${ }^{1}$, Alan Junior de Pelegrin ${ }^{2}$, Ivan \\ Ricardo Carvalho ${ }^{1}$, Velci Queiróz de Souza ${ }^{2}$
}

${ }^{1}$ Universidade Federal de Pelotas, Faculdade de Agronomia Eliseu Maciel, Avenida Eliseu Maciel, CEP: 96160-
000, Capão do Leão, RS, Brazil

${ }^{2}$ Universidade Federal de Santa Maria, Campus de Frederico Westphalen, Linha 7 de Setembro, s/n, BR 386 Km

40, CEP: 98400-000, Frederico Westphalen, RS, Brazil

*Corresponding author: viniciusszareski@gmail.com; pelegrinagro@gmail.com; velciq@gmail.com

\begin{abstract}
Wheat stands out as one of the main agricultural cereals in the world, used in human and animal feed. The aim of this study was to investigate the effect of using different sources and split application of nitrogen fertilizer on the yield performance of wheat genotypes in two farming seasons to develop alternatives for wheat farmers. The experiment was conducted in the experimental area of the Plant Breeding and Production Laboratory, in the farming seasons of 2012 and 2013. A split-plot experimental design was used with six topdressing nitrogen fertilization strategies, three nitrogen sources and five wheat genotypes as treatments. A number of variables such as grain yield, protein percentage in the grains, 1000-grain weight and test weight were assessed. The results showed that split application of nitrogen fertilization in tillering, booting and flowering stages increases the protein percentage $(2.34 \%)$ and does not reduce grain yield due to full implementation of fertilizing at tillering stage. Nitrogen fertilizer in tillering, booting and flowering sources with ammonium nitrate and urea enhanced the grain yield (7.75\%), protein percentage $(11.54 \%)$ using source liquid.
\end{abstract}

Keywords: nitrogen split; productive of wheat; protein; Triticum aestivum; yield components.

Abbreviations: CV_coefficient of variation; E_environment; Estr_estrategy; I_absence of nitrogen; II_tillering; III_tillering and booting; IV_tillering and flowering; V_booting and flowering; VI_tillering, booting and flowering; G_genotype; GY_grain yield; TGW_1000-grain weight; TPP_total protein percentage; TW_test weight.

\section{Introduction}

Wheat is the second most-produced cereal in the world, mainly due to high demand of its derivatives, especially for flour and feed production (Pinnow et al., 2013). The southern region of Brazil accounts for over $90 \%$ of domestic production, especially in the states of Parana and Rio Grande do Sul, which produce around 6 million tons (Conab, 2015). Wheat crop yield is linked to biotic and abiotic factors, especially to genotype, climatic conditions and soil fertility. Regarding fertility, nitrogen is required in high amounts (Kutman et al., 2011), exerting strong influence on yield and other production components (Benin et al., 2012; Xu et al., 2012). However, of the total mineral nitrogen applied to the crop, around 40 to $60 \%$ is used by the plant in its metabolism, in order to perform metabolic functions and to maximize productive performance (Górny et al., 2011; Barraclough et al., 2010).

Nitrogen application time is one of the most important aspects in grasses, as it interferes with grain yield and quality by physiological stimuli. Thus, early or late applications usually show low efficiency due to poor utilization of plants (Kluthcouski et al., 2006). Nitrogen sources through topdressing nitrogen split application increase plant absorption efficiency and reduce losses by volatilization and leaching, resulting in higher grain yield and flour technological quality (Mundstock, 1999; Barraclough et al., 2010).
Wheat flour technological quality is influenced by grain protein percentage. Proteins represent 10 to $15 \%$ of constituents in the grain, and are used to determine grain suitability and destination. The main proteins found in grains are gliadin and glutenin, which account for much of flour functional characteristics, especially for gluten formation (Miranda et al., 2011). Changes in protein levels and quality are affected by soil fertility, genotype characteristics, genotype-environment interaction (GxE) and nitrogen availability (Cazetta et al., 2008). Therefore, the aim of this study was to assess the effect of using different sources and split application of nitrogen fertilizer on yield performance of wheat genotypes in two farming seasons, in order to develop alternatives for wheat farmers.

\section{Results and Discussions}

\section{Characterization of traits}

Analysis of variance showed significant interaction for year $\mathrm{x}$ source $\mathrm{x}$ topdressing nitrogen split fertilization for the grain yield variable. The interaction source $\mathrm{x}$ nitrogen fertilization split was significant for the percentage of proteins in the grain and 1000-grain weight variables. Year $\mathrm{x}$ genotype interaction was significant for 1000-grain weight and proteins in the grain. Regarding quantitative variables, environment 
changes or variations usually cause interference with these variables, due to their genetic complexity (Benin et al., 2004). Test weight variable revealed no interaction between treatment factors, and comparisons were held separately for each factor.

\section{Performance of grain yield for the different nitrogen sources}

With respect to grain yield, the liquid nitrogen source in year I showed higher yield increases in topdressing nitrogen split fertilization at tillering and split at tillering and flowering. In addition, IV strategy did not differ from others. In year II, it was found that splits to that same source showed similar yields, where split $\mathrm{V}$ had higher magnitude, but only differing with split III (Table 1).

Regarding ammonium nitrate source in the year I, II, III, IV, V and VI splits had the highest grain yield. In the year II, it was observed that the best splits were II, III, V and VI. For the urea source in year I, the highest magnitude observed for strategies III and VI, which differed only from strategies I and V. In the year II, strategies II, III, IV, V and VI showed higher magnitudes, differing from strategy I (Table 1).

The strategy that did not receive topdressing nitrogen application had lower grain yield than split periods, in both years and nitrogen sources. Thus, nitrogen applications are essential to obtain grain yield increases, since this element is required at higher concentrations. It has an important role in the structure of amino acid, protein, and pigment molecules, and is part of ion absorption, respiration and photosynthesis processes, which impact grain yield (Malavolta, 2006). Thus, topdressing nitrogen split fertilization directly influences this variable, and its use at single or split doses in tillering, booting and flowering stages result in higher yield increases, when urea and ammonium nitrate are used.

Nitrogen fertilizer split applications in the stages of elongation and flowering result in grain yield increases in relation to full application at sowing, and no differences were noted to the application during tillering stages (GarridoLestache et al., 2004). This result corroborates with Costa et al. (2013), who did not find significance between applications at tillering and booting, indicating that there is no grain quality and grain yield reductions if nitrogen topdressing is delayed. In contrast, split application of nitrogen did not result in grain yield increase for applications after tillering, even if different nitrogen sources were used, such as ammonium nitrate, ammonium sulfate and urea (Yano et al., 2005; Teixeira Filho et al., 2007; Moraes et al., 2013). However, high doses provided in just one application maximized losses by volatilization and leaching, reducing its use by the plant. Thus, split applications at several crop stages may reduce losses by supplying nitrogen at lower doses, enabling better use by the plant throughout the cycle to develop its metabolic activities.

Regarding to grain yield and application of nitrogen sources to different splits and farming seasons, it was observed that urea application had higher magnitudes for strategies III and VI, differing from the liquid application in year I. Applications with ammonium nitrate showed no differences compared to other sources. In that same year, no differences were observed among nitrogen sources for splits II and IV. However, ammonium nitrate split applications were higher than others in the stages of booting and flowering. In the year I, a single dose application during the tillering stage did not show differences between sources. In year II, urea and ammonium nitrate sources achieved the highest magnitudes, differing from the liquid source in application strategies II, III, V and VI. For strategy III, it was observed that urea application was higher than the other sources. Thus, urea and ammonium nitrate application in the wheat crop, in a single application or split, results in higher grain yield compared to nitrogen application in liquid form. When compared to nitrogen foliar application in the flowering stage, grain yield increases were not observed, although there was an increase in grain protein percentage (Woolfolk et al., 2002).

Comparing the farming seasons (Table 1), it was observed that year II was higher than year I in splits VI and V for both nitrogen sources. Regarding splits II and III on year II, the highest magnitudes were obtained for ammonium nitrate and urea sources, differentiating from year I. For the liquid source, no significant differences were observed between years. Years I and II did not differ for strategy I in both sources tested. Based on strategy IV, it was observed that year II was significantly higher than year II with urea application. In contrast, no differences were observed between farming seasons using $\mathrm{N}$ in liquid form and ammonium nitrate. According to Campos et al. (2004), the occurrence of weather abnormalities or the incidence of pests and diseases may influence grain yield components and technological properties of the grains.

\section{Performance of protein for the different nitrogen sources}

Regarding total protein content in the grains for split application of nitrogen fertilization and nitrogen sources, split applications in the late crop stages had the highest grain protein increases for ammonium nitrate and urea sources (Table 2). According to Tonon (2010), protein in the grain is slowly accumulated in wheat endosperm tissues at 20 days after anthesis. During this period, $40 \%$ of proteins are reserved for higher classes, such as glutenin and gliadin, being formed in the grain, and after 45 days, the grain protein stock is complete. In this stage, nitrogen availability is required for protein synthesis in wheat grains. Nutrient deficiency in the plant results in grain protein synthesis decrease and grain starch synthesis increase, generating grains with low protein concentration (Rosa Filho, 2010).

The liquid nitrogen source did not show differences in protein levels in the six splits (Table 2). However, ammonium nitrate showed that splits III, IV, V and VI had an increase in protein content. Urea source showed that the application strategy I had the lowest magnitude compared to other strategies. According to Altenbach et al. (2011), higher protein content in the grain occurs with topdressing nitrogen application during wheat reproductive stage. Another nutrient that influences the percentage of proteins in the grain is sulfur (S). It is responsible for the connections between proteins in the formation of the gluten network (Rosa Filho, 2010).

The VI, V, IV, III and II top dressing nitrogen application strategies showed that ammonium nitrate and urea sources were higher and differed from the liquid source. The result is consistent with the fact that nitrogen applications with slow or fast release do not differ in the final result of grain protein percentage. In contrast, nitrogen foliar application showed unsatisfactory response, when compared to solid sources, as foliar application restricted applied nitrogen use. The leaf area reduces the epidermis stomatal structures absorption area in the early stages, increasing evaporation losses during application (Fontoura and Bayer, 2010). 
Table 1. Mean comparison analysis for the interaction between topdressing nitrogen split fertilization (I: nitrogen absence, II: tillering, III: tillering and booting, IV: tillering and flowering, V: booting and flowering, and VI: tillering, booting and flowering) $\mathrm{x}$ farming season (I: 2012 and II: 2013) x nitrogen source (liquid, ammonium nitrate and urea) for grain yield.

\begin{tabular}{|c|c|c|c|c|c|c|}
\hline \multirow{4}{*}{ Estr. } & \multicolumn{6}{|c|}{ Farming Season } \\
\hline & \multicolumn{3}{|c|}{$\mathrm{I}$} & \multicolumn{3}{|c|}{ II } \\
\hline & \multicolumn{3}{|c|}{ Nitrogen source } & \multicolumn{3}{|c|}{ Nitrogen source } \\
\hline & *Liquid (L) & $\underset{(\mathrm{kg})}{\text { Ammonium Nitrate }}$ & Urea $(\mathrm{kg})$ & Liquid (L) & $\begin{array}{l}\text { Ammonium } \\
\text { Nitrate }(\mathrm{kg})\end{array}$ & Urea (kg) \\
\hline I & $3615.0 \mathrm{~b} \mathrm{~A} \alpha$ & $3614.0 \mathrm{~b} \mathrm{~A} \alpha$ & $3556.1 \mathrm{~b}$ A $\alpha$ & 3767.7 ab A $\alpha$ & 3728.6 с A $\alpha$ & $3608.1 \mathrm{~b} \mathrm{~A} \alpha$ \\
\hline II & 3852.0 a A $\alpha$ & 3826.2 a A $\beta$ & $3751.9 \mathrm{ab} A \beta$ & 3770.2 ab B $\alpha$ & 4139.1 ab A $\alpha$ & 4155.8 a $\mathrm{A} \alpha$ \\
\hline III & $3607.7 \mathrm{~b} \mathrm{~B} \alpha$ & $3816.1 \mathrm{ab} \mathrm{AB} \beta$ & 3844.8 a A $\beta$ & $3605.9 \mathrm{~b} \mathrm{~B} \alpha$ & 4287.3 а $\mathrm{A} \alpha$ & 4108.7 a $\mathrm{A} \alpha$ \\
\hline IV & $3811.9 \mathrm{ab} \mathrm{A} \alpha$ & $3817.9 \mathrm{ab} \mathrm{A} \alpha$ & $3704.3 \mathrm{ab} \mathrm{A} \beta$ & $3770.3 \mathrm{ab} \mathrm{B} \alpha$ & 3948.7 bc B $\alpha$ & 4263.8 a A $\alpha$ \\
\hline V & 3607.4 b B $\beta$ & 3840.8 a $\mathrm{A} \beta$ & 3567.7 b B $\beta$ & 3851.1 a B $\alpha$ & $4161.6 \mathrm{ab} \mathrm{A} \alpha$ & 4316.9 a A $\alpha$ \\
\hline VI & 3588.5 b B $\beta$ & 3756.9ab AB $\beta$ & 3820.4 a A $\beta$ & 3822.0 ab B $\alpha$ & 4234.5 a A $\alpha$ & 4254.0 a A $\alpha$ \\
\hline $\mathrm{CV}(\%)$ & \multicolumn{6}{|c|}{8.64} \\
\hline
\end{tabular}

Means followed by the same lowercase letter (a) in the column for topdressing nitrogen application strategy, by uppercase letter (A) in the line for nitrogen, and by Greek letter $(\alpha)$ to farming season did not differ statistically by Tukey test at $5 \%$ error probability. *nitrogen sources used and their respective units: liters and kg

Table 2. Mean comparison analysis for the interaction between topdressing nitrogen application strategy (I: nitrogen absence, II: tillering, III: tillering and booting, IV: tillering and flowering, V: booting and flowering, and VI: tillering, booting and flowering) and nitrogen source (liquid, ammonium nitrate and urea) for total protein percentage (TPP) and 1000-grain weight (TGW) variables.

\begin{tabular}{|c|c|c|c|c|c|c|}
\hline \multirow[b]{3}{*}{ Estrategy } & \multicolumn{3}{|c|}{ TPP } & \multicolumn{3}{|c|}{ TGW } \\
\hline & \multicolumn{3}{|c|}{ Nitrogen source } & \multicolumn{3}{|c|}{ Nitrogen source } \\
\hline & *Liquid (L) & $\begin{array}{l}\text { Ammonium } \\
\text { Nitrate }(\mathrm{kg})\end{array}$ & Urea $(\mathrm{kg})$ & Liquid (L) & $\begin{array}{c}\text { Ammonium Nitrate } \\
(\mathrm{kg})\end{array}$ & Urea $(\mathrm{kg})$ \\
\hline I & 13.59 a A & 13.55 с $\mathrm{AB}$ & $13.24 \mathrm{~b} \mathrm{~B}$ & $31.16 \mathrm{ab} \mathrm{A}$ & $31.20 \mathrm{ab} \mathrm{A}$ & $31.07 \mathrm{ab} \mathrm{A}$ \\
\hline II & 13.76 a B & $15.04 \mathrm{~b} \mathrm{~A}$ & $15.26 \mathrm{a} \mathrm{A}$ & $31.12 \mathrm{ab} \mathrm{A}$ & $30.81 \mathrm{bc} \mathrm{A}$ & $30.60 \mathrm{~b} \mathrm{~A}$ \\
\hline III & $13.57 \mathrm{a} B$ & $15.34 \mathrm{ab} A$ & $15.55 \mathrm{a} \mathrm{A}$ & $30.78 \mathrm{~b} \mathrm{AB}$ & 30.36 c B & $30.97 \mathrm{ab} \mathrm{A}$ \\
\hline IV & 13.63 a B & $15.26 \mathrm{ab} \mathrm{A}$ & $15.54 \mathrm{a} \mathrm{A}$ & $31.57 \mathrm{a} A$ & $31.70 \mathrm{a} \mathrm{A}$ & 31.42 a A \\
\hline V & $13.70 \mathrm{a} \mathrm{B}$ & $15.45 \mathrm{a} \mathrm{A}$ & 15.56 a A & $31.58 \mathrm{a} \mathrm{A}$ & $31.75 \mathrm{a} \mathrm{A}$ & 31.50 a A \\
\hline VI & 13.68 a B & $15.40 \mathrm{a} \mathrm{A}$ & $15.53 \mathrm{a} \mathrm{A}$ & $31.44 \mathrm{a} \mathrm{A}$ & $31.36 \mathrm{ab} \mathrm{A}$ & $31.11 \mathrm{ab} \mathrm{A}$ \\
\hline $\mathrm{CV}(\%)$ & \multicolumn{3}{|c|}{4.28} & \multicolumn{3}{|c|}{3.60} \\
\hline
\end{tabular}

Table 3. Mean comparison analysis for the interaction between genotype (TBIO Itaipu, Quartzo, TBIO Iguaçu, Fundacep 52 and TBIO Mestre) and farming season (I: 2012 and II: 2013) determining the total protein percentage (\%) (TPP) and 100-grain weight (TGW), in grams.

\begin{tabular}{|c|c|c|c|c|}
\hline \multirow{3}{*}{ Genotype } & \multicolumn{2}{|c|}{ TPP } & \multicolumn{2}{|c|}{ TGW } \\
\hline & \multicolumn{2}{|c|}{ Farming season } & \multicolumn{2}{|c|}{ Farming season } \\
\hline & $\mathrm{I}$ & III & I & III \\
\hline TBIO Itaipu & $14.24 \mathrm{c} \mathrm{A}$ & 13.37 e B & $31.46 \mathrm{~b} \mathrm{~A}$ & 29.58 c B \\
\hline Quartzo & $14.37 \mathrm{bc} \mathrm{A}$ & $13.66 \mathrm{~d} \mathrm{~B}$ & $33.42 \mathrm{a} \mathrm{A}$ & $32.32 \mathrm{a} \mathrm{B}$ \\
\hline TBIO Iguaçu & $14.48 \mathrm{~b} \mathrm{~A}$ & $14.16 \mathrm{c} \mathrm{B}$ & $33.12 \mathrm{a} \mathrm{A}$ & $31.41 \mathrm{~b} \mathrm{~B}$ \\
\hline Fundacep 52 & 15.49 a A & $15.04 \mathrm{~b} \mathrm{~B}$ & $31.69 \mathrm{~b} \mathrm{~A}$ & $29.07 \mathrm{~d} \mathrm{~B}$ \\
\hline TBIO Mestre & $15.55 \mathrm{a} A$ & 15.54 a A & $31.47 \mathrm{~b} \mathrm{~A}$ & 28.41 e B \\
\hline $\mathrm{CV}(\%)$ & \multicolumn{2}{|c|}{4.28} & \multicolumn{2}{|c|}{3.64} \\
\hline
\end{tabular}

* Means followed by the same lowercase letter (a) in the column for genotype and by the same capital letter (A) in the line for farming season do not differ statistically by Tukey test at $5 \%$ error probability.

Table 4. Mean results for test weight (TW) and grain yield (GY) variables in different wheat genotypes.

\begin{tabular}{lcc}
\hline Genotype & $\mathrm{TW}\left(\mathrm{kg} \mathrm{hl}^{-1}\right)$ & $\mathrm{GY}\left(\mathrm{kg} \mathrm{ha}^{-1}\right)$ \\
\hline TBIO Itaipu & $77.46 \mathrm{ab}$ & $3918.25 \mathrm{ab}$ \\
Quartzo & $76.86 \mathrm{bc}$ & $4240.78 \mathrm{a}$ \\
TBIO Iguaçu & $78.41 \mathrm{a}$ & $3844.23 \mathrm{~b}$ \\
Fundacep 52 & $77.00 \mathrm{bc}$ & $3610.67 \mathrm{~b}$ \\
TBIO Mestre & $75.94 \mathrm{c}$ & $3660.31 \mathrm{~b}$ \\
\hline CV $(\%)$ & 3.56 & 8.64 \\
\hline *Means followed by the same lowercase letter (a) in the column do not differ statistically the Tukey at 5\% error probability.
\end{tabular}


Performance of 1000-grain weight due to different nitrogen sources

For the 1000-grain weight variable, there was interaction between topdressing nitrogen split application and nitrogen source (Table 2). For liquid nitrogen and ammonium nitrate sources, strategy III had lower magnitudes, differing from strategies IV, V and VI. Regarding urea use, it was found that the highest magnitudes were obtained in strategies IV and V. The remaining application splits did not differ, although strategy II had the lowest magnitude. Thus, it is evident that nitrogen split in different crop stages directly influences 1000 -grain weight, because it reduces losses by volatilization and allows continuous supply to the plant. Studies by Yano et al., (2005), Bredemeier and Mundstock (2001) found that nitrogen fertilization in wheat provided higher 1000-grain weight when conducted during booting, compared to early applications.

Regarding the effect of nitrogen sources on 1000-grain weight (Table 2), urea use in strategy III was higher than the other sources, and there were no differences between the nitrogen fertilization splits. Thus, the way nitrogen is supplied to the plant does not influence on 1000-grain weight. It corroborates with results by Silva et al. (2005), who also showed that 1000 -grain weight did not differ for nitrogen sources, and only the treatment without nitrogen application differed from other fertilizer application periods. Studies conducted by Teixeira Filho et al. (2010), with the aim of assessing the influence of different nitrogen sources in the wheat crop, found that 1000 -grain weight was influenced by different nitrogen sources, highlighting ammonium sulfate and $E_{n t e c}{ }^{\circledR}$, which are products of slow nitrogen release, making the element available for longer periods during the crop.

Regarding grains total protein percentage, it became clear that genotypes had different behavior among them and in relation to the farming season. Difference between genotypes may be due to differences in the genetic constitution, as it is a quantitative character expressed by a large number of genes, and each protein is encoded by at least one gene. In addition, genotypes are greatly influenced by alleles from the loci encoding them (Brammer, 2000). According to Sangoi et al. (2007), genotypes with different genetic bases also have a different response to topdressing nitrogen application strategies.

During the farming season I, it was observed that TBIO Mestre and Fundacep 52 genotypes showed the highest total protein percentages (Table 3 ), being different from the others. TBIO Itaipu genotype had the lowest magnitude, although was not different from the Quartzo genotype. In year II, significant differences were observed among all genotypes, and TBIO Mestre genotype was higher. According to Rosa Filho (2010) protein levels in the grains of wheat genotypes may vary from $8 \%$ to $18 \%$, and ideal genotypes for breadmaking must have at least $12 \%$ protein. Thus, all genotypes obtained higher protein percentages than $12 \%$ for the two farming seasons, highlighting TBIO Mestre and Fundacep 52 genotypes, with protein percentages higher than $15 \%$. However, there are differences between the protein composition of these genotypes, and TBIO Mestre has higher technical qualities due to higher concentrations of glutenin and gliadin proteins, which increase gluten strength, stability and falling number.

Comparing crop years (Table 3), it is evident that the highest magnitudes occurred in the year I, differing from year II, TBIO Iguaçu, TBIO Itaipu, Quartzo and Fundacep 52, abd only the TBIO Mestre genotype remained constant along the years. Thus, climate variables influenced grain protein percentage, and rainfall, relative humidity, global solar radiation, maximum temperature and soil water excess negatively influenced grain protein percentage (Guarienti et al., 2003).

Genotypes had different behavior with respect to 1000grain weight in the crop years. In year I, it was observed that the Quartzo and TBIO Iguaçu genotypes were higher than the other genotypes. In year II, all genotypes showed significant differences for this variable, and Quartzo genotype showed the highest magnitude, followed by TBIO Iguaçu, TBIO Itaipú, Fundacep 52 and TBIO Mestre. The 1000-grain weight is positively correlated to grain size. Thus, among the genotypes analyzed, Quartzo stood out as best in both farming seasons.

In the comparison between years (Table 3), it was observed that year I was higher than Year II to 1000-grain weight variable. Environmental conditions that occurred in year I were very favorable for the production and translocation of photoassimilates produced in the active photosynthetic parts to the grains, increasing dry matter accumulation and resulting in increased grain specific mass. Lower number of grains formed by plants affects 1000-grain weight, as the photoassimilates produced are distributed to a lower number of grains, changing the grain size and dry weight. According to Guarienti et al. (2005), this variable is influenced by genetic factors and environmental factors, such as temperature, humidity and rainfall during the ripening stage.

\section{Performance of weight test due to different nitrogen sources}

Weight test indirectly express grain quality, as it is an indicator that reflects grain yield for flour or semolina. Thus, industrial yield tends to be higher according to the grain test weight (Oliveira, 2012). Values considered optimal for industry are above $78 \mathrm{~kg} \mathrm{hl}^{-1}$ (Megda et al., 2009).

For the test weight variable, differences were not observed regarding farming season, topdressing nitrogen split application and nitrogen source. Differences were only observed with respect to wheat genotypes. Thus, nitrogen split application does not result in test weight increase through the nature of the nitrogen source; even the form of nitrogen released into the soil is changed. Contrasting data was found by Teixeira Filho et al. (2010), who studied three nitrogen sources in wheat crops and found that test weight was significantly influenced by nitrogen sources. Urea provided higher test weight than ammonium sulfate, but did not differ statistically from Entec $®$. The same author also found that nitrogen application fully applied at sowing did not differ significantly from topdressing application for test weight.

Test weight values (Table 4) ranged from 75.94 to $78.41 \mathrm{~kg}$ $\mathrm{hl}^{-1}$, and the highest magnitude was observed for TBIO Iguaçu genotype, differing from Quartzo, Fundacep 52 and TBIO Mestre genotypes. According to the Normative Instruction No. 38, November 30, 2010, from the Ministry of Agriculture, Livestock and Supply (MAPA), Wheat Technical Regulation commercially classifies wheat into three types. Type I, with minimum TW of $78 \mathrm{~kg} \mathrm{hl}^{-1}$, Type II, with minimum TW of $75 \mathrm{~kg} \mathrm{hl}^{-1}$ and Type III, with minimum TW of $72 \mathrm{~kg} \mathrm{hl}^{-1}$. Thus, genotypes tested may be grouped based on test weight in type I (TBIO Iguaçu) and type II (TBIO Itaipu, Fundacep 52, Quartzo and TBIO Mestre).

With respect to grain yield, wheat genotypes tested did not interact with nitrogen fertilizer split, nitrogen source and 
farming season. Contrasting results were only observed between wheat genotypes, corroborating results by Megda et al. (2009), who assessed ammonium nitrate, ammonium sulfate and urea sources, in which no direct effect on productivity was observed. Silva et al. (2008), using two nitrogen sources for no tillage, found no implication on grain yield. Da Ros et al. (2003) did not find significant differences between nitrogen application forms on wheat crop. Similar yields were found, regardless of application form, which could be during pre-sowing, seeding or topdressing, and nitrogen doses split also did not promote significant yield increase.

Quartzo genotype had the highest magnitude in the grain yield variable, was not differing only from TBIO Itaipu genotype (Table 4). The results showed that wheat genotypes tested had high productive potentials, which were expressed through the environmental conditions and the management employed. Quartzo genotype stood out, having the highest yield. Regarding mean results, it is observed that genotypes which stood out in relation to the grain protein percentage obtained the lowest grain yields, as these variables contrast. The inverse relationship between protein percentage and wheat grain yield is confirmed by Schmidt et al. (2009); Trethowan et al. (2001). According to Freitas et al. (2007), grain yield is a characteristic that has quantitative inheritance and is defined through the interaction of several yield components, which are controlled by genotype genetic factors and the environment.

\section{Materials and Methods}

\section{Plant materials}

The experiment was conducted at the Federal University of Santa Maria, Frederico Westphalen Campus, RS state, in the experimental area of the Plant Breeding and Production Laboratory, under $27^{\circ} 23^{\prime} 48.17^{\prime \prime} \mathrm{S}, 53^{\circ} 25^{\prime} 34.82$ " coordinates and $460 \mathrm{~m}$ altitude. The soil is classified as Oxisol (Santos et al., 2006), and the climate is humid subtropical, with balanced rainfall and no dry season. The average annual rainfall ranges between 1,250 and 2,000 $\mathrm{mm}$ (Sema, 2005).

\section{Experimental design and experimental procedure}

The experiment was conducted through randomized blocks in a split-plot design, with five genotypes, three nitrogen sources and six periods of topdressing nitrogen split fertilization. The five genotypes were, as follows: Fundacep 52, TBIO Mestre and TBIO Itaipu, TBIO Iguaçu and Quartzo. The three nitrogen sources were, as follows: Urea 45\% nitrogen and $\mathrm{AN}$ : ammonium nitrate $-33.5 \%$ nitrogen and liquid nitrogen. The six periods of topdressing nitrogen split fertilization were, as follows: I: absence of nitrogen, II: tillering, III: tillering and booting, IV: tillering and flowering, $\mathrm{V}$ : booting and flowering, and VI: tillering, booting and flowering.

The experimental unit consisted of 12 rows with $0.17 \mathrm{~m}$ spacing between each row and $3.5 \mathrm{~m}$ length, totaling $7.14 \mathrm{~m}^{2}$. For the assessments, the eight central rows were collected and $0.5 \mathrm{~m}$ was eliminated from the ends of the plot. Sowing was conducted in 2012 on 25 May and on July 10 in the 2013 farming season, with the aid of a tractor and planter set. The base fertilizer used for both farming seasons was $200 \mathrm{~kg} \mathrm{ha}^{-1}$ NPK formulation (08-24-12), and $115 \mathrm{~kg} \mathrm{ha}^{-1}$ nitrogen was applied through topdressing in all plots. The average plant population was of 310 plant $\mathrm{m}^{2}$.
Crop treatments were performed in accordance with the technical recommendations for wheat crop. Regarding pest and diseases control, applications were conducted preventively, according to constant observation throughout the crop cycle.

\section{Traits measured}

The variables analyzed were: Grain yield (GY): obtained through the total mass of grains of each experimental unit, corrected to $13 \%$ moisture and extrapolated to $\mathrm{kg} \mathrm{ha}^{-1}$. 1000grain weight (TGW): measured through manual counting of eight repetitions of 100 grains, expanded to the 1000-grain weight in grams (g) afterwards. Total Protein Percentage (TPP): determined by nondestructive near-infrared analysis through INFRATECTM 1241 Grain Analyzer, using eight 100 g subsamples. Results were expressed in percentage (\%). Test weight (TW): determined through the grain mass per volume unit with a test weight scale. Results were expressed in $\mathrm{kg} \mathrm{hl}^{-}$ 1

\section{Statistical analysis}

Data were submitted to analysis of variance by F-test. When significant interaction between treatment factors was revealed, simple effects were analyzed. Variables that showed no significant interaction had their main effects analyzed. Averages were compared by Tukey test at $5 \%$ error probability. Analyses were performed through Genes software (Cruz, 2013).

\section{Conclusion}

Nitrogen fertilization split during tillering, booting and flowering stages impacts in protein percentage increase and does not imply grain yield reduction in relation to tillering full application. For 1000-grain weight, this strategy implies in increase compared to other strategies. Ammonium nitrate and urea sources increase grain yield, protein percentage and 1000 -grain weight compared to nitrogen foliar application.

TBIO Mestre genotype stands out for grain protein percentage, showing its potential for the production of flour. For grain yield and 1000-grain weight, Quartzo genotype had the highest levels.

\section{References}

Altenbach SB, Tanaka CK, Hurkman WJ, Vensel WH, Dupont FM (2011) Differential effects of a post-anthesis fertilizer regimen on the wheat $\mathrm{fl}$ our proteome determined by quantitative 2-DE. Proteome Sci. 46(9):1-13.

Barraclough PB, Howarth JR, Jones J, Lopez-Bellido R, Parmar S, Shepherd CE, Hawkesford MJ (2010) Nitrogen efficiency of wheat: genotypic and environmental variation and prospects for improvement. Eur J Agron. 33(1):1-11.

Benin G, Bornhofen E, Beche E, Pagliosa ES, Silva CL, Pinnow C (2012) Agronomic performance of wheat cultivars in response to nitrogen fertilization levels. Acta Sci-Agron. 34(3):275-283.

Benin G, Carvalho FIF, Oliveira AC, Silva JAG, Lorencetti C, Maia MB, Marchioro VS, Freitas F, Hartwig I (2004) Uma proposta de seleção para caracteres quantitativos e qualitativos em aveia. Cienc Rural. 34(3):701-706.

Brammer SP (2000) Marcadores moleculares: princípios básicos e uso em programas de melhoramento genético vegetal. Embrapa Trigo, Passo Fundo. 
Bredemeier C, Mundstock CM (2001) Estádios fenológicos do trigo para a adubação nitrogenada em cobertura. Rev Bras Cienc Solo. 25(2):317-323.

Campos LAC, Dotto SR, Brunetta D (2004) Informações técnicas das comissões centro-sul brasileira de pesquisa de trigo e de triticale para a safra de 2004. Embrapa Soja, Londrina. p 214.

Cazetta DA, Fornasieri Filho D, Arf O, Germani R (2008) Qualidade industrial de cultivares de trigo e triticale submetidos à adubação nitrogenada no sistema de plantio direto. Bragantia 67(3):741-750.

Conab - Companhia Nacional de Abastecimento (2015) Acompanhamento da safra brasileira: safra 2015 de trigo. Available at: http://www.conab.gov.br/OlalaCMS/uploads/arquivos/15_07 09_08_59_32_boletim_graos_julho_2015.pdf>. Accessed on July 20, 2015.

Costa L, Zucareli C, Riede CR (2013) Parcelamento da adubação nitrogenada no desempenho produtivo de genótipos de trigo. Rev Cienc Agron. 44(2):215-224.

Cruz CD (2013) Genes - a software package for analysis in experimental statistics and quantitative genetics. Acta SciAgron. 35(3):271-276.

Da Ros CO, Salet RL, Machado JNC (2003) Disponibilidade de nitrogênio e produtividade de milho e trigo com diferentes métodos de adubação nitrogenada no sistema plantio direto. Cienc Rural. 33(5):799-804.

Fontoura SMV, Bayer C (2010) Ammonia volatilization in no-till system in the south-central region of the stale of paraná, Brazil. Rev Bras Cienc Solo. 34(5):1677-1684.

Freitas JG, Cantarella H, Salomon MV, Malavolta VMA, Castro LHSM, Gallo PB, Azzini LE (2007) Produtividade de cultivares de arroz irrigado resultante da aplicação de doses de nitrogênio. Bragantia 66(2):317-325.

Garrido-Lestache E, López-Bellido RJ, López-Bellido L (2004) Effect of $\mathrm{N}$ rate, timing and splitting and $\mathrm{N}$ type on breadmaking quality in hard red spring wheat under rainfed mediterranean conditions. Field Crop Res. 85(2-3):213-236.

Górny AG, Banaszak Z, Lugowska B, Ratajczak D (2011) Inheritance of the efficiency of nitrogen uptake and utilization in winter wheat (Triticum aestivum L.) under diverse nutrition levels. Euphytica. 177(2):191-206.

Guarienti EM, Ciacco CF, Cunha GR, Del Duca LJA, Camargo CMO (2003) Avaliação do efeito de variáveis meteorológicas na qualidade industrial e no rendimento de grãos de trigo pelo emprego de análise de componentes principais. Ciencia Tecnol Alime. 23(3):500-510

Guarienti EM, Ciacco CF, Cunha GR, Del Duca LJA, Camargo CMO (2005) Efeitos da precipitação pluvial, da umidade relativa do ar e de excesso de déficit hídrico do solo no peso hectolitro, no peso de mil grãos e no rendimento de grãos de trigo. Ciencia Tecnol Alime. 25(3):412-418.

Kluthcouski J, Aidar H, Thung M, Oliveira FRA (2006) Manejo antecipado do nitrogênio nas principais culturas anuais. Embrapa Arroz e Feijão, Brasília.

Kutman UB, Yildiz B, Cakmak I (2011) Improved nitrogen status enhances zinc and iron concentrations both in the whole grain and the endosperm fraction of wheat. J Cereal Sci. 53(1):118-125.

Malavolta E (2006) Manual de nutrição de plantas. Agronômica Ceres, São Paulo.

Megda MM, Buzetti S, Andreotti M, Teixeira Filho MMC, Vieira MX (2009) Resposta de cultivares de trigo ao nitrogênio em relação às fontes e épocas de aplicação sob plantio direto e irrigação por aspersão. Cienc Agrotec. 33(4):1055-1060.

Mapa - Ministério Da Agricultura Pecuária e Abastecimento (2010) Instrução Normativa $\mathrm{n}^{\circ} 38$, de 30 de novembro de 2010. Brasil. Available at: http://www.codapar.pr.gov.br/arquivos
/File/pdf/TrigoInstrucaoNormativa3810.pdf. Accessed on July $25,2015$.

Miranda MZ, Guarienti EM, Tonon VD (2011) Qualidade tecnológica de trigo. In: Pires JLF, Vargas L, Cunha GR (Ed.) Trigo no Brasil: bases para a produção competitiva e sustentável. Embrapa, Passo Fundo.

Moraes LBD, Freo JD, Biduski B, Elias MC, Gutkoski LC (2013) Effects of rate, time and splitting of nitrogen fertilization on the technological quality of wheat. J Food Sci Eng. 3(1):9-18.

MUNDSTOCK CM (1999) Planejamento e manejo integrado da lavoura de trigo. Evangraf, Porto Alegre.

Oliveira KS (2012) Stresse térmico em plantas de trigo. Alterações na composição do grão. Dissertation (Master in Food Technology and Safety). Universidade Nova de Lisboa.

Pinnow C, Benin G, Viola R, Silva CLS, Gutkoski LC, Cassol LC (2013) Qualidade industrial do trigo em resposta à adubação verde e doses de nitrogênio. Bragantia 72(1):20-28.

Rosa Filho O (2010) Introdução ao manejo para qualidade industrial em trigo. Informativo Técnico Biotrigo 1(1):01-06.

Sangoi L, Berns AC, Almeida ML, Zanin CG, Schweitzer C (2007) Características agronômicas de cultivares de trigo em resposta à época da adubação nitrogenada de cobertura. Cienc Rural. 37(6):1564-1570.

Santos HG, Jacomine PKT, Anjos LHC, Oliveira VA, Oliveira JB, Coelho MR, Lumbreras JF, Cunha TJF (Ed.) (2006) Sistema brasileiro de classificação de solos. 2.ed. Rio de Janeiro: Embrapa Solos, 306p.

Schmid DAM, Carvalho FIF, Oliveira AC, Silva JAG, Bertan I, Valério IP, Hartwig I, Silveira G, Gutkoski LC (2009) Variabilidade genética em trigos brasileiros a partir de caracteres componentes da qualidade industrial e produção de grãos. Bragantia 68(1):43-52.

Sema - Secretaria Estadual Do Meio Ambiente (2005) Plano de manejo do parque estadual do turvo. Porto Alegre. Available at:http://www.sema.rs.gov.br/upload/Plano_manejo_PETurvo. pdf. Accessed on July 30, 2015.

Silva PRF, Strieder ML, Coser RPS, Rambo L, Sangoi L, Argenta G, Forsthofer EL, Silva AA (2005) Grain yield and kernel protein content increases of maize hybrids with late nitrogen side-dressing. Sci Agr. 62(5):487-492.

Silva AS, Arf O, Buzetti S, Silva MG (2008) Fontes e épocas de aplicação de nitrogênio em trigo em sistema plantio direto no cerrado. Rev Bras Cienc Solo. 32(9):2717-2722.

Teixeira Filho MCM, Buzetti S, Alvarez RCF, Freitas JG, Arf O, Sá ME (2007) Resposta de cultivares de trigo irrigado por aspersão ao nitrogênio em cobertura na região do Cerrado. Acta Sci-Agron. 29(3):421-425.

Teixeira Filho MCM, Buzetti S, Andreotti M, Arf O, Benett CGS (2010) Doses, fontes e época de aplicação de nitrogênio em trigo irrigado em plantio direto. Pesqui Agropecu Bras. 45(8):797-804.

Tonon VD (2010) Herança genética e estabilidade de características relacionadas à qualidade dos grãos e da farinha de trigo. PhD Thesis. Universidade Federal do Rio Grande do Sul.

Trethowan RM, Peña RJ, Van Ginkel M (2001) The effect of indirect test grain quality on the grain yield and industrial quality of bread wheat. Plant Breeding. 120(6):509-512.

Xu G, Fan X, Miller AJ (2012) Plant nitrogen assimilation and use efficiency. Annu Rev Plant Biol. 63(6):153-82.

Yano GT, Takahashi HW, Watanabe TS (2005) Avaliação de fontes de nitrogênio e épocas de aplicação em cobertura para o cultivo do trigo. Semin-Cienc Agrar. 26(2):141-148.

Woolfolk CW, Raum WR, Johnson GV, Thomason WE, Mullen RW, Wynn KJ, Freeman KM (2002) Influence of late-season foliar nitrogen applications on yield and grain nitrogen in winter wheat. Agron J. 94(3):429-434. 